\title{
REVIEW
}

\section{ESTRADIOL SYNTHESIS WITHIN THE HUMAN BRAIN}

\author{
I. AZCOITIA, ${ }^{\text {a* }}$ J. G. YAGUE ${ }^{\mathrm{b}}$ AND L. M. GARCIA-SEGURA ${ }^{\mathrm{c}}$ \\ aBiología Celular, Facultad de Biología, Universidad Complutense de \\ Madrid, E-28040 Madrid, Spain

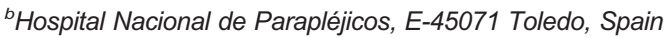 \\ 'Instituto Cajal, CSIC, E-28002 Madrid, Spain
}

\begin{abstract}
Estradiol biosynthesis is catalyzed by the enzyme aromatase, the product of the CYP19A1 gene. Aromatase is expressed in the brain, where it is involved not only in the control of neuroendocrine events and reproduction, but also in the regulation of neural development, synaptic plasticity and cell survival. In this review we summarize the existing data related with the detection of aromatase in human brain, with particular emphasis in the so-called "non-primary reproductive" areas. Besides hypothalamus, amygdala and preoptic/septal areas, aromatase is expressed in certain regions of basal forebrain, cerebral cortex, hippocampus, thalamus, cerebellum and brainstem of the human brain. Aromatase in human brain is produced by neurons, but there is also an astrocyte subpopulation that constitutively expresses the enzyme. The use of different methodological approaches, including the in vivo analysis by positron emission tomography of human subjects, has permitted to draw a general map of human brain aromatase, but the detailed distribution map is still far to be completed. On the other hand, despite the fact that there is only one aromatase protein, there are multiple mRNA transcripts that differ in the 5'-untranslated region, where regulatory elements reside. To date, some of the aromatase transcripts characteristic of cerebral cortex, as well as of human cell lines of neural origin, have been identified. This characteristic may confer tissue or even region-specific regulation of the expression and therefore it is conceivable to develop selective aromatase modulators to regulate the expression of the enzyme in the human brain.

This article is part of a Special Issue entitled: Neuroactive Steroids: Focus on Human Brain. () 2011 IBRO. Published by Elsevier Ltd. All rights reserved.
\end{abstract}

Key words: aromatase, estrogen receptors, estrogens, human brain, local estradiol synthesis.

\begin{tabular}{ll}
\multicolumn{2}{c}{ Contents } \\
Aromatase Expression & 140 \\
Enzyme activity assay & 140 \\
Immunocytochemistry & 140 \\
mRNA expression & 141 \\
Positron emission tomography (PET) imaging & 143 \\
Brain Estrogen Biosynthesis in the Human Brain: To What & \\
$\quad$ Extent? & 143 \\
\hline
\end{tabular}

*Corresponding author. Tel: +34-913945127; fax: +34-91-3944981. E-mail address: azcoitia@bio.ucm.es (I. Azcoitia).

Abbreviations: PET, positron emission tomography; RT-PCR, reverse transcriptase-polymerase chain reaction. $\begin{array}{lr}\text { Conclusion } & 145\end{array}$

Acknowledgments 145

References $\quad 145$

Aromatase, the product of CYP19A1 gene, is the enzyme that synthesizes estrogens from androgen precursors. It is a cytochrome p450 protein of the family 19A, also known as P450AROM, estrogen synthase or estrogen synthetase. Fig. 1 depicts the three possible aromatase catalyzed reactions in which 19 carbon atom precursors are consecutively oxidized, hydroxylated and finally demethylated to render 18 carbon atom estrogens, wearing the characteristic phenolic ring (Boon et al., 2010). The estrogens produced in a given tissue depend on the bioavailability of substrates. In the case of human brain, the three precursors shown in Fig. 1 have been isolated (Schindler, 1975; Hammond et al., 1983; Milewich et al., 1986).

Aromatase activity or expression has been described in several brain regions and different cell types in all vertebrates, from fish to primates (Callard et al., 1977, 1978; Selmanoff et al., 1977; Steimer and Hutchison, 1980; MacLusky et al., 1986). Human brain aromatase activity was first described by Naftolin and collaborators in fetal hypothalamus (Naftolin et al., 1971a) and limbic system (Naftolin et al., 1971b). These findings perfectly matched with the role proposed for testosterone and estradiol in brain sex determination and the control of sex behavior (Harris and Levine, 1965; Westley and Salaman, 1976; McEwen et al., 1977; for reviews see Morris et al., 2004; Bakker and Baum, 2008; Wright et al., 2010). Thus, the concept of brain regions involved in the central reproductive control emerged. These regions include the hypothalamus, the preoptic area and the amygdala. Later on, alternative roles for sex steroids in the brain were discovered, acting in what it has been called "non-primary brain sex areas". These new roles of sex hormones in the brain include the regulation of neuronal survival, the modulation of synaptic function and the control of neurogenesis (Azcoitia et al., 2001; Garcia-Segura et al., 2001; Kretz et al., 2004; Martinez-Cerdeno et al., 2006; Pawluski et al., 2009; see Garcia-Segura, 2008; Boon et al., 2010 for reviews). Moreover, it has also been described scenarios in which reproductive and non-reproductive areas converge to cope with unexpected roles. For instance, estradiol is part of the hormonal system modulating the amygdala-prefrontal cortex emotion circuit (Van Wingen, 2011); related to this, it is worthy to point out that both amygdala neurons (Roselli et al., 1998) and prefrontal cortex astrocytes (Luchetti et al., in press; Luchetti and Swaab, 2011) express aromatase. All these functions and others described in reproductive, skele- 


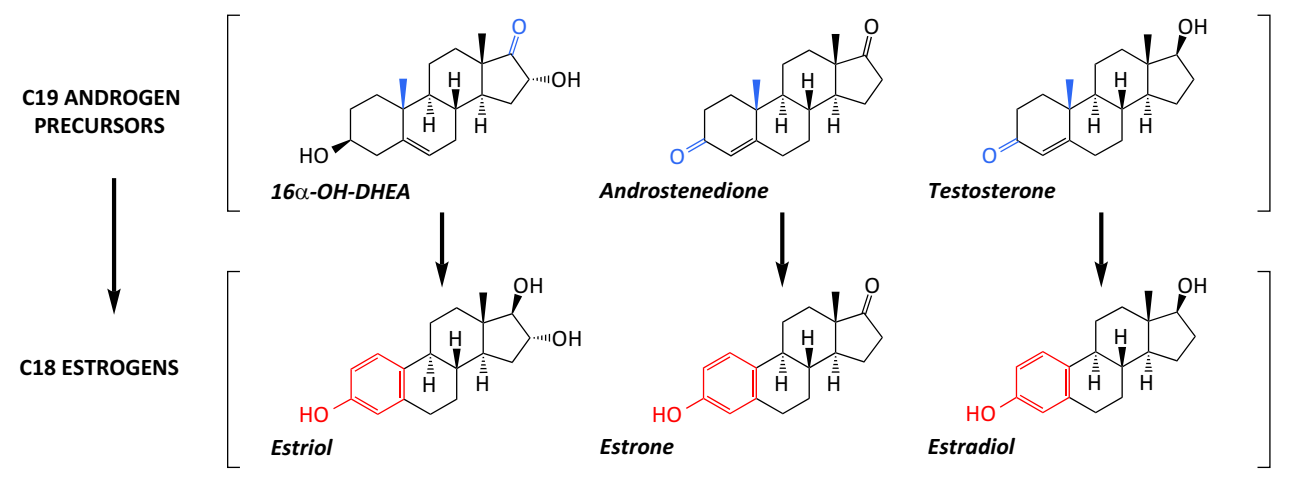

Fig. 1. Aromatization of precursor androgens by aromatase enzyme (CYP19A1 gene). Reactive groups are highlighted in blue and the resulting phenolic ring, characteristic of estrogens, in red.

tal, cardiovascular and adipose tissues, make estrogens key elements "involved in the maintenance of general physiological homeostasis in both sexes" (Simpson and Jones, 2006).

In this review, we will focus mainly in the non-reproductive sphere of estrogens in brain. We will consider data on aromatase expression. For functional and gene regulation data, the reader is referred to recent reviews in the field (Garcia-Segura, 2008; Roselli et al., 2009; Boon et al., 2010).

\section{AROMATASE EXPRESSION}

Brain aromatase has been evidenced by enzyme activity assays, protein expression (immunocytochemistry, Western blotting), mRNA expression (in situ hybridization and reverse transcriptase-polymerase chain reaction) gene transcription and binding of radioactive labeled inhibitors that generate positron emission tomography (PET) images. There is not a complete correlation in the results obtained with these different techniques, which could be explained in terms of methodological limitations, but also due to differences in stability of the products: for instance, shortlive transcripts that translate into stable protein or viceversa; or protein modifications that can hide/expose the epitope against a particular anti-aromatase antibody.

\section{Enzyme activity assay}

One of the most extended assays is the in vitro radiometric method, based on the release of radioactive water after supplying radiolabeled (mostly tritiated) androgens to tissue homogenates (Weisz, 1982). This was the method used by Naftolin in the first descriptions of aromatase activity in human hypothalamus (Naftolin et al., 1971a) and limbic system (Naftolin et al., 1971b). Aromatase activity has been also demonstrated in hippocampus and cerebral cortex of non-human primates during late fetal and early postnatal life (MacLusky et al., 1987) and human temporal cortex from postmortem samples (Wozniak et al., 1998) and biopsies (Steckelbroeck et al., 1999). Cortical enzyme activity seems to be unrelated to sex or age differences (Steckelbroeck et al., 1999). The enzyme assay is also positive in human cell lines (Wozniak et al., 1998) and human astrocytomas (Weidenfeld and Schiller, 1984).

\section{Immunocytochemistry}

Aromatase immunoreactivity in human brain has been described in hypothalamus, preoptic area and amygdala (Ishunina et al., 2005). Besides these reproductive brain centers, aromatase has been localized in cholinergic basal forebrain (Ishunina et al., 2005) in temporal (Yague et al., 2006) and prefrontal cortices (Luchetti et al., in press), as well as in hippocampal formation, including both dentate gyrus and Ammon's horn CA1-CA4 sectors (Ishunina et al., 2007; Yague et al., 2010). Aromatase immunoreactivity is reduced in the hippocampus of Alzheimer disease patients (Ishunina et al., 2007), but it remains intact in individuals affected by epilepsy (Yague et al., 2010). On the other hand, a clear increase in aromatase immunoreactivity has been detected in the basal forebrain (nucleus basalis of Meynert) during normal aging (Ishunina et al., 2005). Related to the effect of circulating estrogens in aromatase expression, there is not a complete study in humans, but it remains unaltered in non-human primates hippocampus, comparing intact versus ovariectomized females (Yague et al., 2008). This result is in agreement with the data of enzyme activity assay of human biopsies obtained during neurosurgical partial resection of the temporal lobe (Steckelbroeck et al., 1999, see former subsection).

With respect to cell types, mammalian brain aromatase is mostly expressed in neurons, but there are also some immunoreactive glia cells. Neurons expressing aromatase in the temporal cortex of human and non-human primates and in human hippocampus are both principal (pyramidal and dentate granule cells) and different types of interneurons (Yague et al., 2006, 2008, 2010). Neuronal aromatase is present in perikarya, dendrites and axons (Yague et al., 2006). Aromatase containing axon terminals establish synapses with both aromatase immuno-negative and immuno-positive dendrites and somata (Naftolin et al., 1996). Estradiol locally produced within the synapse is thought to regulate synaptogesis (Kretz et al., 2004), neurotransmission (Balthazart and Ball, 2006) and synaptic plasticity (Mukai et al., 2010; Zhou et al., 2010).

Glia cells expressing aromatase in non-primate mammals include astrocytes in primary cultures (Azcoi- 
tia et al., 2003), gliomas (Yague et al., 2004), cortical progenitor glia (Martinez-Cerdeno et al., 2006), or astrocytes in brain areas submitted to different types of lesion (Garcia-Segura et al., 1999, 2003). Human aromatase immunoreactivity in glia has been described in ependymal cells and choroid plexus ependymal (Ishunina et al., 2005), human glioblastoma cell lines (Yague et al., 2004) and prefrontal and temporal cerebral cortices (Yague et al., 2006; Luchetti et al., in press). Aromatase expression in human hippocampal glia has been described in astrocytes (Ishunina et al., 2007; Yague et al., 2010). Interestingly, hippocampal human astrocytes do not behave as those in other mammals and do not express the enzyme in certain stressful conditions, such as epilepsy (Yague et al., 2010).

\section{mRNA expression}

Besides some few studies in non-human mammals in which mRNA expression has been demonstrated by in situ hybridization (Roselli et al., 2001), the main body of data comes from reverse transcriptase-polymerase chain reaction (RT-PCR). First PCR descriptions of aromatase in human brain came from fetal material (Toda et al., 1994). In fact, the two key regulatory proteins of estrogen synthesis, namely the Steroidogenic Acute Regulatory protein (StAR), placed at the beginning of the pathway, and aromatase, at the end of the pathway, have been detected by PCR in human fetal brain (Pezzi et al., 2003). In adults, different aromatase transcripts have been found in several brain regions, including pons, thalamus, hypothalamus and hippocampus, of both women and men (Sasano et al., 1998). StoffelWagner et al. (1998) found aromatase transcription in human temporal cortex. No differences between men and women have been described in temporal cortex mRNA levels, but there are significantly higher values in adults than in children (Stoffel-Wagner et al., 1998). Hippocampus and to a lesser extent frontal cortex are also involved in aromatase transcription (Stoffel-Wagner et al., 1999). Confirming immunocytochemical analysis, aromatase transcripts have been found in prefrontal cortex, where quantitative PCR studies showed increased mRNA levels (as much as 2.4-fold higher) in Alzheimer's disease patients, compared to matched controls (Luchetti et al., in press). In contrast, the hippocampus shows a significant down-regulation in aromatase transcripts in Alzheimer's disease subjects compared to controls (Ishunina et al., 2007). This apparent discrepancy could be due to a possible swift neuron-toastroglia aromatase expression. As it happens in the hippocampus, prefrontal cortex neurons from Alzheimer's disease patients show a reduced aromatase transcription, but astrocytes, particularly those in layers 2 and 3 , over-express the enzyme (Luchetti et al., in press). The astroglial expression of aromatase may compensate for the reduction in neuronal expression and even result in a higher global value. In the case of the hippocampal formation, the drop in aromatase neuronal transcription cannot be compensated, probably because human hippocampal astrocytes do not synthetize aromatase, either in normal or stress conditions, as efficiently as cortical astrocytes do (see at the end of the former sub-section).

Human CYP19A1 gene consists of nine coding exons and a 5'- unstranslated region, containing alternative promoter and untranslated first exons. To date, 11 different first exons have been reported in human aromatase (Boon et al., 2010) that may confer tissue-specific regulation of its expression. Sasano et al. (1998) identified the so-called brain transcript $1 \mathrm{f}$, plus $1 \mathrm{~b}$ and $1 \mathrm{~d}$ transcripts [corresponding respectively to 1.4 and PII in Simpson's nomenclature (Boon et al., 2010)]. Yague et al. (2006) confirmed the use

Table 1. Summary of findings on aromatase and estrogen receptors distribution in human brain

\begin{tabular}{|c|c|c|c|c|c|c|}
\hline \multirow[t]{2}{*}{ Brain region } & \multicolumn{4}{|c|}{ Aromatase } & \multirow[b]{2}{*}{$\mathrm{ER} \alpha$} & \multirow[b]{2}{*}{$\mathrm{ER} \beta$} \\
\hline & EAA & ICC & RT-PCR & PET & & \\
\hline Cerebral cortex & 1,2 & 3,4 & $1,3,5$ & 6 & 7 & 7 \\
\hline Hippocampus & & 8,9 & 5,10 & & 8,11 & 7 \\
\hline Basal forebrain & & 12 & & & 13 & 7 \\
\hline Basal ganglia & & & & 6 & & \\
\hline Preoptic area, hypothalamus and amygdala & 14,15 & 12 & 10 & 6 & 7,16 & 7,17 \\
\hline Thalamus & & & 10 & 6 & 7 & 7 \\
\hline Cerebellum & & & & 6 & 13,18 & 18 \\
\hline Pons & & & 10 & 6 & 13 & \\
\hline Medulla & & & & 6 & 12 & \\
\hline Gliomas & 19 & 20 & 4,20 & & 20 & \\
\hline Neuroblastomas & & & 4 & & 18 & \\
\hline
\end{tabular}

For aromatase expression, examples of several experimental approaches are presented, while estrogen receptor expression is mainly based on immunocytochemical and mRNA detection methods. Most of the data are based on adult subjects. EAA, enzyme activity assay; ICC, immunocytochemistry; RT-PCR, reverse transcriptase-polymerase chain reaction; PET, positron emission tomography; ER $\alpha$, estrogen receptor alpha; ER $\beta$, estrogen receptor beta. 1: Wozniak et al., 1998; 2: Steckelbroeck et al., 1999; 3: Luchetti et al., in press; 4: Yague et al., 2006; 5: Stoffel-Wagner et al., 1999; 6: Biegon et al., 2010; 7: Osterlund et al., 2000; 8: Ishunina et al., 2007; 9: Yague et al., 2010; 10: Sasano et al., 1998; 11: Ishunina and Swaab, 2008; 12: Ishunina et al., 2005; 13: Ishunina and Swaab, 2009; 14: Naftolin et al., 1971a; 15: Naftolin et al., 1971b; 16: Kruijver et al., 2002; 17: Kruijver et al., 2003; 18: Belcher et al., 2009; 19: Weidenfeld and Schiller, 1984; 20: Yague et al., 2004. 
of exons I.f, I.4 and PII and described also the exon I.3T (the truncated form of I.3) in human temporal cortex. They also analyzed aromatase transcription in the human cell lines glioblastoma multiforme T98G, glioblastoma-astrocytoma U373 and neuroblastoma SHSY5Y (Yague et al., 2004,2006 ), confirming that all these cell lines transcribe aromatase. They use the same promoters identified in temporal cortex, that is, PII, I.3T, I.f and I.4 and a new one, the 1.7 exon that could be a signature of transformed neural cells. The list of aromatase promoter exons seems not having an end, and recently it has been described the exon I.8, which makes the 11th in its class (Demura et al., 2008). Expression of this exon was extremely low in fetal human brain, but acquires certain significance in adults.

The mechanisms and factors that regulate the activity of the different promoters in the aromatase gene in the human brain need to be systematically explored. This will allow a selective regulation of aromatase ex-

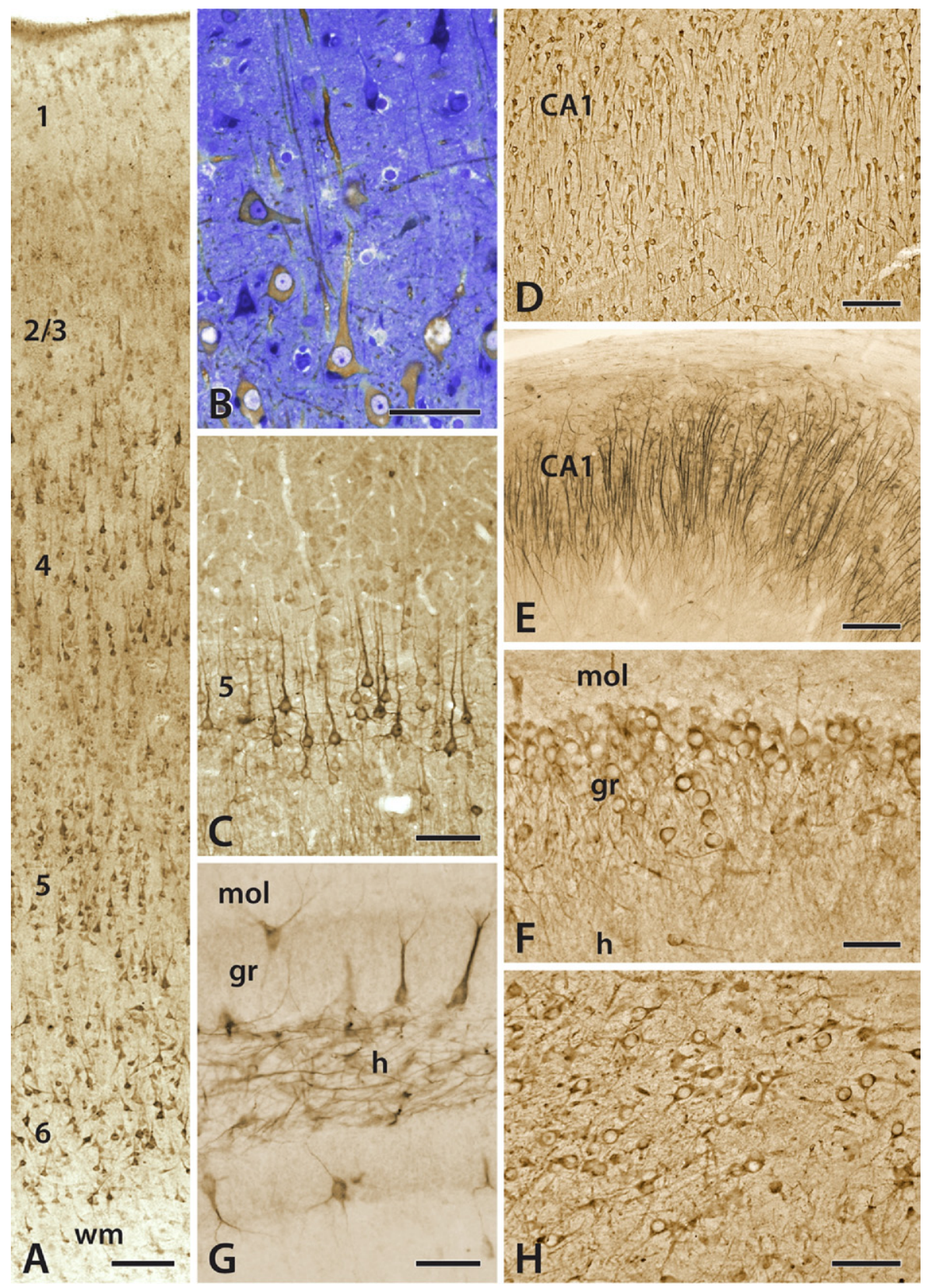

Fig. 2. Aromatase expression in cerebral cortex and hippocampus. Aromatase expressing cells appear through the entire human cortex (A), from layers 1-6 and in white matter (wm). Panel (B) depicts some pyramidal cells, in which aromatase is distributed in perikarya and processes. Rodent cortical pyramidal cells also express aromatase $(C)$, but mainly restricted to layer 5 . In human hippocampus, pyramidal cells (D), granular cells $(F)$ and hilar interneurons $(H)$, are aromatase immunoreactive. A similar pattern can be seen in rodent Ammon's horn $(E)$, but in dentate gyrus $(G)$ only very few granular and hilar neurons are aromatase positive. CA1, sector 1 of Cornu Ammonis; gr, granular cell layer of dentate gyrus; h, dentate hilus; mol, dentate molecular layer. Scale bars: $(A)=300 \mu \mathrm{m} ;(B, C, E, H)=100 \mu \mathrm{m} ;(G, F)=50 \mu \mathrm{m} ;(D)=200 \mu \mathrm{m}$. 
pression in different brain regions. In this aspect, there are already some data on aromatase transcription regulation in human glioma and neuroblastoma cell lines (Yague et al., 2009).

\section{Positron emission tomography (PET) imaging}

Brain aromatase can be evidenced in vivo by the use of radiolabeled inhibitors of the enzyme that specifically bind to it, allowing the analysis of aromatase distribution based on PET studies. Aromatase inhibitor election is critical and certain third-generation inhibitors, such as letrozole that are currently used in clinics due to their high inhibitory activity, are not the most efficient, because of their relatively low affinity (Kil et al., 2009). Vorozole, a second generation inhibitor with a higher affinity (close to 15 fold), seems more appropriate for the analysis of brain aromatase distribution (Takahashi et al., 2006). Recently, Biegon et al. (2010) administered [N-methyl-11C] vorozole to six young, healthy voluntaries, three men and three women and observed the brain distribution of the radiotracer. They found that the higher content of aromatase was in thala- mus, followed by amygdala, preoptic area and medulla oblongata. There was also a significant binding in temporal and occipital cortices, basal ganglia, cerebellum, pons and white matter.

\section{BRAIN ESTROGEN BIOSYNTHESIS IN THE HUMAN BRAIN: TO WHAT EXTENT?}

Comparing the heterogeneity in results obtained in different studies, the question is to determine how generalized is estrogen synthesis within the human brain. Is estrogen production only efficient when in large amounts, as in the hypothalamus, or even minute and extremely localized estrogen production matters, as it could be the case for synaptic plasticity modulation? Is the synthesis a sustained episode or rather a series of short events that could be misinterpreted as artifacts? Generally speaking, some molecular biology approaches, show a much restricted aromatase distribution than immunological methods, PCR, enzyme activity assays or PET. In a gene expression study in mouse with engineered aromatase co-expressing two reporter genes, positive signal was only found in preoptic

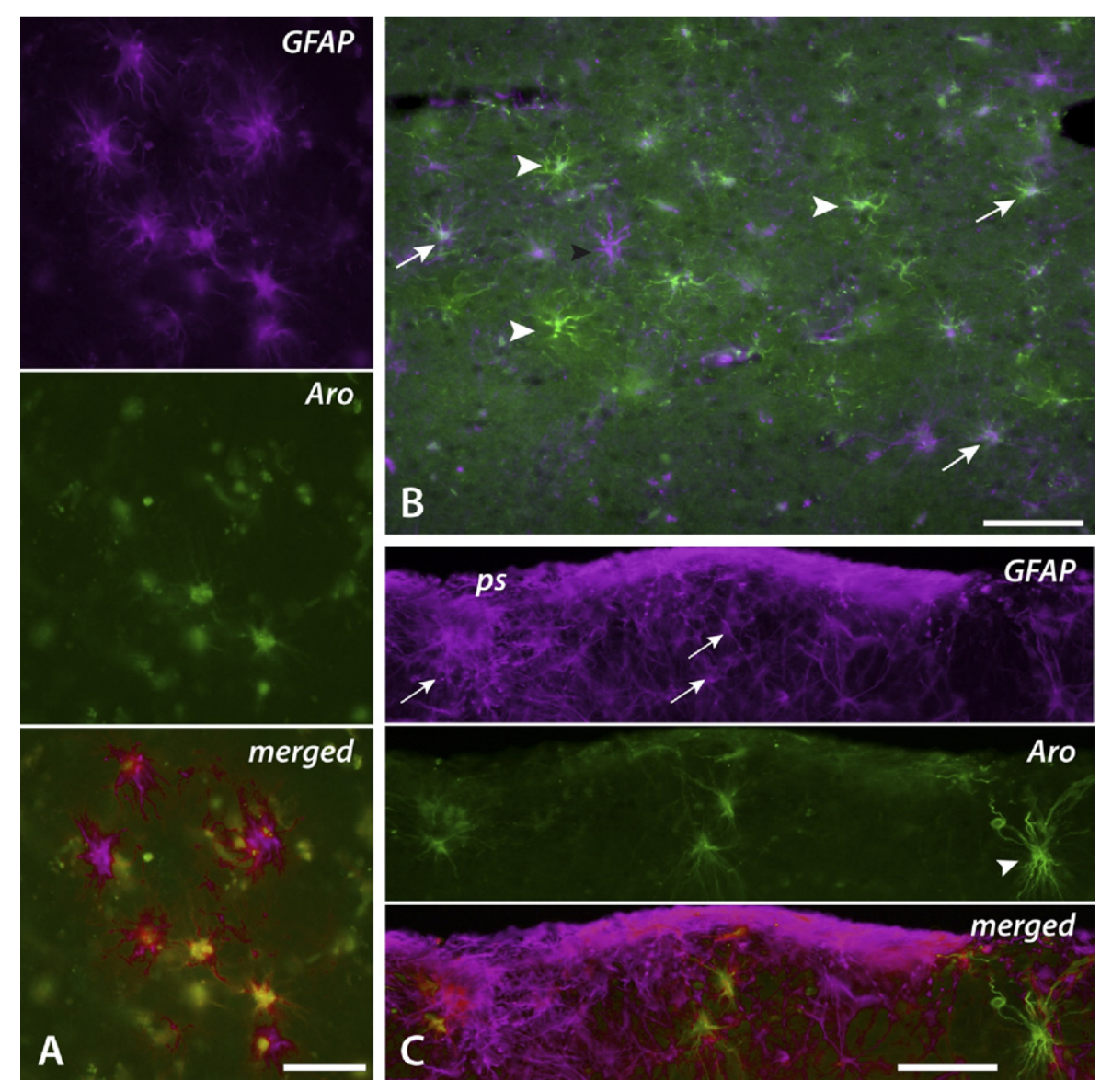

Fig. 3. Aromatase expression in human cortical astrocytes. Colocalization of GFAP and aromatase can be seen in superficial (A) and deep (B) white matter associated to cerebral cortex. Most of the astrocytes in white matter close to cortical layer 6 (A) colocalize both proteins, while in deeper white matter (B), there are colocalizing cells (arrows), GFAP expressing only astrocytes (black arrowheads) and aromatase only expressing cells morphologically resembling astrocytes (white arrowheads). Similarly, only a fraction of interlaminar astrocytes of cortical layer 1 (C) colocalizes aromatase and GFAP (arrows); the most do not express the enzyme and few aromatase cells with astrocytic aspect are not GFAP stained (arrowhead). Scale bars: $(A)=50 \mu \mathrm{m} ;(B, C)=100 \mu \mathrm{m}$. 
area, hypothalamus and amygdala (Wu et al., 2009). Similar results have been obtained by in situ hibrydization studies (http://www.ncbi.nlm.nih.gov/gensat, Cyp19a1), but other molecular biology techniques, such as RT-PCR (Munetsuna et al., 2009), immunocytochemistry (Hojo et al., 2004), enzyme activity assays (Konkle and McCarthy, 2011), or PET images (Takahashi et al., 2006) confirm that aromatase is also present in many other brain areas. The generalized expression of aromatase can also be inferred by the fact that these mentioned areas accumulate estradiol, as measured by liquid chromatography followed by tandem mass spectrometry (Konkle and McCarthy, 2011). Furthermore, cerebral inhibition of aromatase, abolish brain-specific estrogen actions, such as hippocampal neuroprotection (Azcoitia et al., 2001), olfactory bulb neurogenesis (Veyrac and Bakker, in press), neuron survival (Hill et al., 2009), reduced reeelin expression in CajalRetzius cells (Bender et al., 2010) or vestibular nuclei long-term potentiation (Grassi et al., 2009). To conclude, it is worthy to note that there is a positive correlation between aromatase expression and estrogen receptors distribution (Gillies and McArthur, 2010). This correlation is shown in Table 1 that summarizes the main findings on aromatase and estrogen receptors distribution in human brain.

The difficulties to obtain postmortem human material in appropriate conditions for the analysis is a limiting factor for a complete study of the areas implicated in estrogen production. Trying to reproduce in the human brain the results obtained in lower mammals can be a good start. In this regard, after finding aromatase immunoreactive neurons in cerebral cortex and hippocampus in rodents, we processed human cortex and hippocampus confirming that these areas were also aromatase positive in humans. Indeed, immunoreactivity is more generalized in human brain: as it is shown in Fig. 2, aromatase is mainly restricted to pyramidal neurons in layer $\mathrm{V}$ in rodent's cortex, while in humans aromatase positive neurons are both pyramidal cells and interneurons, distributed through all cortical strata. Similarly, in rodent hippocampus the staining is particularly intense in apical dendrites of CA pyramidal cells but restricted to few granular cells, while in humans, CA cell bodies and most of the granular cells are immunopositive (Fig. 2). Special mention deserves glia: in non-primate brain, aromatase immunoreactive astrocytes are absent, unless a lesion had been induced, while in human brain, there are astrocytes that constitutively express the enzyme. For instance, some interlaminar astrocytes (Fig. 3), a subclass exclusive of primates that localize at cortical layer 1 (Oberheim et al., 2009), express aromatase, as do some astrocytes in deeper layers and in the white matter. These astrocytes are only a small fraction of the total astroglia population, and interestingly, some cells morphologically identical to astrocytes that do not express GFAP, are aromatase immunoreactive (Fig. 3). Other glial cell types can be involved in estrogen synthesis;
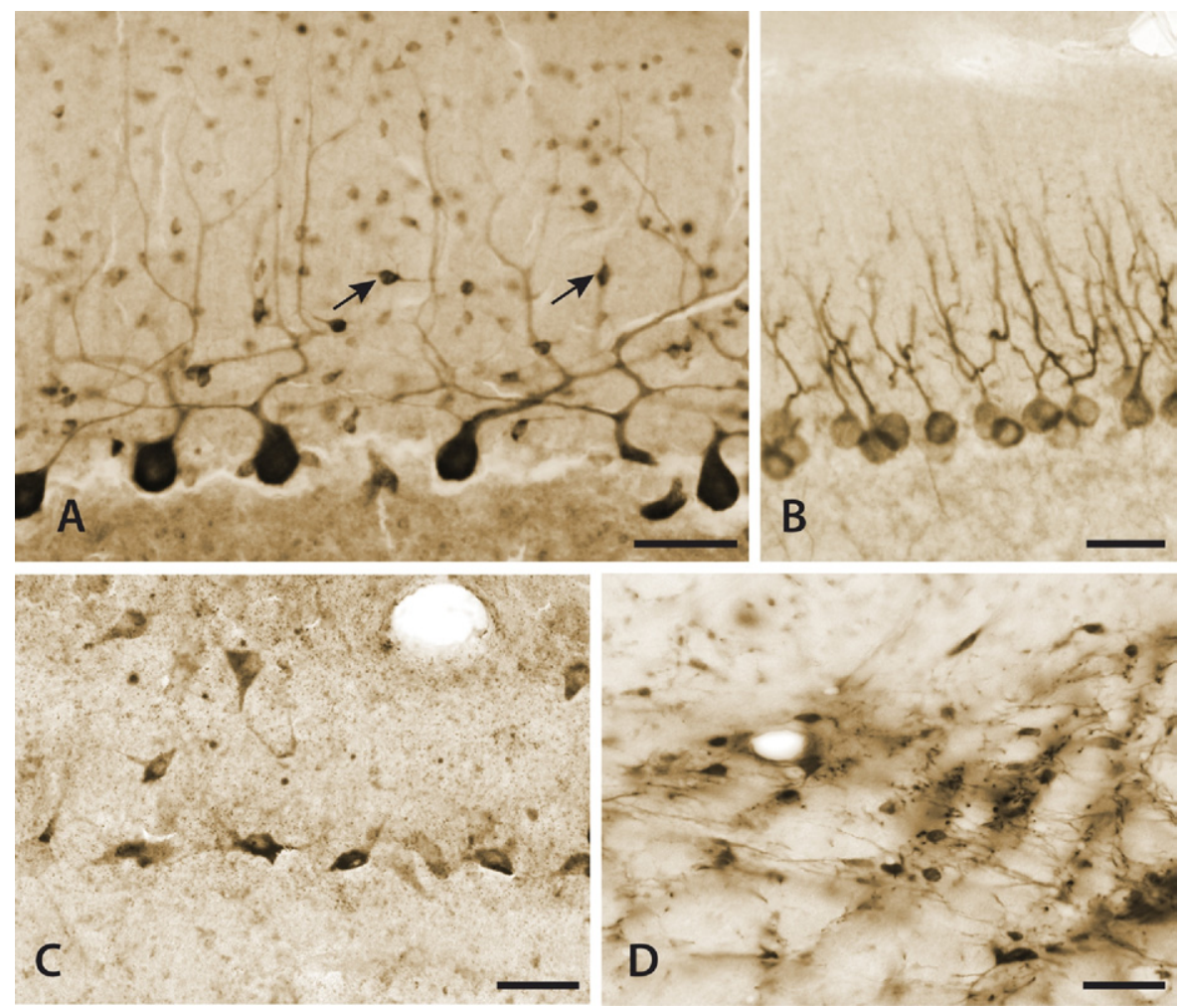

Fig. 4. Aromatase expression in cerebellum and thalamus. Human cerebellum expresses aromatase in Purkinje cells and molecular layer interneurons (arrows), but not in granular cells (A), while in mouse cerebellum, only Purkinje cells are immunoreactive (B). There are also several cell groups expressing aromatase in diencephalon, such as thalamic reticular nucleus, both in man $(C)$ and in mouse $(D)$. Scale bars: $(A)=100 \mu m ;(B-D)=50$ $\mu \mathrm{m}$. 
aromatase immunoreactive ependymal and subependymal cells detected in rodents have been also described in humans (Ishunina et al., 2005).

Aromatase expression in rodent cerebellum and thalamus is also observed in human brain. In mouse cerebellum, only Purkinje cells are immunoreactive, while in humans the staining is observed in Purkinje cells and in interneurons (Fig. 4). With respect to the thalamus, several nuclei express aromatase in rodents, being reticular nucleus one of the deepest stained. Once again, human thalamus exhibits a corresponding immunoreactivity (Fig. 4) that perfectly matches with PET observations (Biegon et al., 2010). Finally, the high level of [N-methyl-11C] vorozole binding by inferior olivary complex observed in humans perfectly fits with the enhanced neurodegeneration in rat inferior olive after aromatase inhibition in an experimental lesion model (Sierra et al., 2003).

\section{CONCLUSION}

Local estradiol synthesis in the human brain seems to be a more extended phenomenon than initially supposed. However, a detailed map of the human brain regions expressing aromatase is still missing. It is also unknown whether different promoters of the aromatase gene are used in different brain regions to regulate aromatase expression. The use of non-invasive in vivo techniques of determination paralleled with the systematic study of aromatase expression in postmortem brain or brain biopsies is a mandatory first step to conduct thereafter a systematic RT-PCR analysis of the different transcripts of aromatase mRNA in different brain regions. At the same time, the mechanisms and factors that regulate the activity of the different promoters in the aromatase gene in the human brain need to be explored.

Acknowledgments-The authors thank Prof. Lydia DonCarlos for the critical reading of the manuscript. This work has been supported by grant BFU2008-02950-C03-01/02 of the Ministerio de Ciencia e Innovación, Spain.

\section{REFERENCES}

Azcoitia I, Sierra A, Veiga S, Garcia-Segura LM (2003) Aromatase expression by reactive astroglia is neuroprotective. Ann N Y Acad Sci 1007:298-305.

Azcoitia I, Sierra A, Veiga S, Honda S, Harada N, Garcia-Segura LM (2001) Brain aromatase is neuroprotective. J Neurobiol 47:318-329.

Bakker J, Baum MJ (2008) Role for estradiol in female-typical brain and behavioral sexual differentiation. Front Neuroendocrinol 29:1-16.

Balthazart J, Ball GF (2006) Is brain estradiol a hormone or a neurotransmitter? Trends Neurosci 29:241-249.

Belcher SM, Ma X, Le HH (2009) Blockade of estrogen receptor signaling inhibits growth and migration of medulloblastoma. Endocrinology 150:1112-1121.

Bender RA, Zhou L, Wilkars W, Fester L, Lanowski JS, Paysen D, Konig A, Rune GM (2010) Roles of $17 \beta$-estradiol involve regulation of reelin expression and synaptogenesis in the dentate gyrus. Cereb Cortex 20:2985-2995.

Biegon A, Kim SW, Alexoff DL, Jayne M, Carter P, Hubbard B, King P, Logan J, Muench L, Pareto D, Schlyer D, Shea C, Telang F, Wang GJ, Xu Y, Fowler JS (2010) Unique distribution of aromatase in the human brain: in vivo studies with PET and [N-methyl-11C]vorozole. Synapse 64:801-807.

Boon WC, Chow JD, Simpson ER (2010) The multiple roles of estrogens and the enzyme aromatase. Prog Brain Res 181:209-232.

Callard GV, Petro Z, Ryan KJ (1977) Identification of aromatase in the reptilian brain. Endocrinology 100:1214-1218.

Callard GV, Petro Z, Ryan KJ (1978) Phylogenetic distribution of aromatase and other androgen-converting enzymes in the central nervous system. Endocrinology 103:2283-2290.

Demura M, Reierstad S, Innes JE, Bulun SE (2008) Novel promoter I.8 and promoter usage in the CYP19 (aromatase) gene. Reprod Sci 15:1044-1053.

Garcia-Segura LM (2008) Aromatase in the brain: not just for reproduction anymore. J Neuroendocrinol 20:705-712.

Garcia-Segura LM, Azcoitia I, DonCarlos LL (2001) Neuroprotection by estradiol. Prog Neurobiol 63:29-60.

Garcia-Segura LM, Veiga S, Sierra A, Melcangi RC, Azcoitia I (2003) Aromatase: a neuroprotective enzyme. Prog Neurobiol 71:31-41.

Garcia-Segura LM, Wozniak A, Azcoitia I, Rodriguez JR, Hutchison RE, Hutchison JB (1999) Aromatase expression by astrocytes after brain injury: implications for local estrogen formation in brain repair. Neuroscience 89:567-578.

Gillies GE, McArthur S (2010) Estrogen actions in the brain and the basis for differential action in men and women: a case for sexspecific medicines. Pharmacol Rev 62:155-198.

Grassi S, Frondaroli A, Dieni C, Scarduzio M, Pettorossi VE (2009) Long-term potentiation in the rat medial vestibular nuclei depends on locally synthesized 17beta-estradiol. J Neurosci 29:10779-10783.

Hammond GL, Hirvonen J, Vihko R (1983) Progesterone, androstenedione, testosterone, 5 alpha-dihydrotestosterone and androsterone concentrations in specific regions of the human brain. $J$ Steroid Biochem 18:185-189.

Harris GW, Levine S (1965) Sexual differentiation of the brain and its experimental control. J Physiol 181:379-400.

Hill RA, Chua HK, Jones ME, Simpson ER, Boon WC (2009) Estrogen deficiency results in apoptosis in the frontal cortex of adult female aromatase knockout mice. Mol Cell Neurosci 41:1-7.

Hojo Y, Hattori TA, Enami T, Furukawa A, Suzuki K, Ishii HT, Mukai H, Morrison JH, Janssen WG, Kominami S, Harada N, Kimoto T, Kawato S (2004) Adult male rat hippocampus synthesizes estradiol from pregnenolone by cytochromes P45017alpha and P450 aromatase localized in neurons. Proc Natl Acad Sci U S A 101: 865-870.

Ishunina TA, Fischer DF, Swaab DF (2007) Estrogen receptor alpha and its splice variants in the hippocampus in aging and Alzheimer's disease. Neurobiol Aging 28:1670-1681.

Ishunina TA, Swaab DF (2008) Estrogen receptor-alpha splice variants in the human brain. Gynecol Endocrinol 24:93-98.

Ishunina TA, Swaab DF (2009) Hippocampal estrogen receptor-alpha splice variant TADDI in the human brain in aging and Alzheimer's disease. Neuroendocrinology 89:187-199.

Ishunina TA, van Beurden D, van der Meulen G, Unmehopa UA, Hol EM, Huitinga I, Swaab DF (2005) Diminished aromatase immunoreactivity in the hypothalamus, but not in the basal forebrain nuclei in Alzheimer's disease. Neurobiol Aging 26:173-194.

Kil KE, Biegon A, Ding YS, Fischer A, Ferrieri RA, Kim SW, Pareto D, Schueller MJ, Fowler JS (2009) Synthesis and PET studies of [(11)C-cyano]letrozole (Femara), an aromatase inhibitor drug. Nucl Med Biol 36:215-223.

Konkle ATM, McCarthy MM (2011) Developmental time course of estradiol, testosterone, and dihydrotestosterone levels in discrete regions of male and female rat brain. Endocrinology 152:223-235.

Kretz O, Fester L, Wehrenberg U, Zhou L, Brauckmann S, Zhao S, Prange-Kiel J, Naumann T, Jarry H, Frotscher M, Rune GM (2004) Hippocampal synapses depend on hippocampal estrogen synthesis. J Neurosci 24:5913-5921. 
Kruijver FP, Balesar R, Espila AM, Unmehopa UA, Swaab DF (2002) Estrogen receptor-alpha distribution in the human hypothalamus in relation to sex and endocrine status. J Comp Neurol 454:115-139.

Kruijver FP, Balesar R, Espila AM, Unmehopa UA, Swaab DF (2003) Estrogen-receptor-beta distribution in the human hypothalamus: similarities and differences with ER alpha distribution. J Comp Neurol 466:251-277.

Luchetti S, Bossers K, Van de Bilt S, Agrapart V, Morales RR, Frajese GV, Swaab DF (in press) Neurosteroid biosynthetic pathways changes in prefrontal cortex in Alzheimer's disease. Neurobiol Aging; doi: 10.1016/j.neurobiolaging.2009.12.014.

Luchetti S, Swaab DF (2011).

MacLusky NJ, Clark AS, Naftolin F, Goldman-Rakic PS (1987) Estrogen formation in the mammalian brain: possible role of aromatase in sexual differentiation of the hippocampus and neocortex. Steroids $50: 459-474$

MacLusky NJ, Naftolin F, Goldman-Rakic PS (1986) Estrogen formation and binding in the cerebral cortex of the developing rhesus monkey. Proc Natl Acad Sci U S A 83:513-516.

Martinez-Cerdeno V, Noctor SC, Kriegstein AR (2006) Estradiol stimulates progenitor cell division in the ventricular and subventricular zones of the embryonic neocortex. Eur J Neurosci 24:3475-3488.

McEwen BS, Lieberburg I, Chaptal C, Krey LC (1977) Aromatization: important for sexual differentiation of the neonatal rat brain. Horm Behav 9:249-263.

Milewich L, MacDonald PC, Carr BR (1986) Estrogen 16 alpha-hydroxylase activity in human fetal tissues. J Clin Endocrinol Metab 63:404-406.

Morris JA, Jordan CL, Breedlove SM (2004) Sexual differentiation of the vertebrate nervous system. Nat Neurosci 7:1034-1039.

Mukai H, Kimoto T, Hojo Y, Kawato S, Murakami G, Higo S, Hatanaka Y, Ogiue-Ikeda M (2010) Modulation of synaptic plasticity by brain estrogen in the hippocampus. Biochim Biophys Acta 1800:1030-1044.

Munetsuna E, Hattori M, Komatsu S, Sakimoto Y, Ishida A, Sakata S, Hojo Y, Kawato S, Yamazaki T (2009) Social isolation stimulates hippocampal estradiol synthesis. Biochem Biophys Res Commun 379:480-484.

Naftolin F, Horvath TL, Jakab RL, Leranth C, Harada N, Balthazart J (1996) Aromatase immunoreactivity in axon terminals of the vertebrate brain. An immunocytochemical study on quail, rat, monkey and human tissues. Neuroendocrinology 63:149-155.

Naftolin F, Ryan KJ, Petro Z (1971a) Aromatization of androstenedione by the diencephalon. $\mathrm{J}$ Clin Endocrinol Metab 33:368-370.

Naftolin F, Ryan KJ, Petro Z (1971b) Aromatization of androstenedione by limbic system tissue from human foetuses. J Endocrinol 51:795-796.

Oberheim NA, Takano T, Han X, He W, Lin JHC, Wang F, Xu Q, Wyatt JD, Pilcher W, Ojemann JG, Ransom BR, Goldman SA, Nedergaard M (2009) Uniquely hominid features of adult human astrocytes. J Neurosci 29:3276-3287.

Osterlund MK, Gustafsson JA, Keller E, Hurd YL (2000) Estrogen receptor beta (ERbeta) messenger ribonucleic acid (mRNA) expression within the human forebrain: distinct distribution pattern to ERalpha mRNA. J Clin Endocrinol Metab 85:3840-3846.

Pawluski JL, Brummelte S, Barha CK, Crozier TM, Galea LA (2009) Effects of steroid hormones on neurogenesis in the hippocampus of the adult female rodent during the estrous cycle, pregnancy, lactation and aging. Front Neuroendocrinol 30:343-357.

Pezzi V, Mathis JM, Rainey WE, Carr BR (2003) Profiling transcript levels for steroidogenic enzymes in fetal tissues. J Steroid Biochem Mol Biol 87:181-189.

Roselli CE, Abdelgadir SE, Ronnekleiv OK, Klosterman SA (1998) Anatomic distribution and regulation of aromatase gene expression in the rat brain. Biol Reprod 58:79-87.

Roselli CE, Klosterman S, Resko JA (2001) Anatomic relationships between aromatase and androgen receptor mRNA expression in the hypothalamus and amygdala of adult male cynomolgus monkeys. J Comp Neurol 439:208-223.
Roselli CE, Liu M, Hurn PD (2009) Brain aromatization: classic roles and new perspectives. Semin Reprod Med 27:207-217.

Sasano H, Takashashi K, Satoh F, Nagura H, Harada N (1998) Aromatase in the human central nervous system. Clin Endocrinol (Oxf) 48:325-329.

Schindler AE (1975) Metabolism of androstenedione and testosterone in human fetal brain. Prog Brain Res 42:330.

Selmanoff MK, Brodkin LD, Weiner RI, Siiteri PK (1977) Aromatization and 5alpha-reduction of androgens in discrete hypothalamic and limbic regions of the male and female rat. Endocrinology 101:841-848.

Sierra A, Azcoitia I, Garcia-Segura L (2003) Endogenous estrogen formation is neuroprotective in model of cerebellar ataxia. Endocrine 21:43-51.

Simpson ER, Jones ME (2006) Of mice and men: the many guises of estrogens. Ernst Schering Found Symp Proc (1):45-67.

Steckelbroeck S, Heidrich DD, Stoffel-Wagner B, Hans VH, Schramm J, Bidlingmaier F, Klingmuller D (1999) Characterization of aromatase cytochrome P450 activity in the human temporal lobe. J Clin Endocrinol Metab 84:2795-2801.

Steimer T, Hutchison JB (1980) Aromatization of testosterone within a discrete hypothalamic area associated with the behavioral action of androgen in the male dove. Brain Res 192: 586-591.

Stoffel-Wagner B, Watzka M, Schramm J, Bidlingmaier F, Klingmuller D (1999) Expression of CYP19 (aromatase) mRNA in different areas of the human brain. J Steroid Biochem Mol Biol 70:237-241.

Stoffel-Wagner B, Watzka M, Steckelbroeck S, Schwaab R, Schramm J, Bidlingmaier F, Klingmuller D (1998) Expression of CYP19 (aromatase) mRNA in the human temporal lobe. Biochem Biophys Res Commun 244:768-771.

Takahashi K, Bergstrom M, Frandberg P, Vesstrom EL, Watanabe $Y$, Langstrom B (2006) Imaging of aromatase distribution in rat and rhesus monkey brains with [11C]vorozole. Nucl Med Biol 33:599-605.

Toda K, Simpson ER, Mendelson CR, Shizuta Y, Kilgore MW (1994) Expression of the gene encoding aromatase cytochrome P450 (CYP19) in fetal tissues. Mol Endocrinol 8:210-217.

Van Wingen $G$ (2011).

Veyrac A, Bakker $\mathrm{J}$ (in press) Postnatal and adult exposure to estradiol differentially influences adult neurogenesis in the main and accessory olfactory bulb of female mice. FASEB J. DOI: 10.1096/fj. 10-172635.

Weidenfeld J, Schiller H (1984) Metabolism of steroids by human brain tumors. Clin Neuropharmacol 7:395-397.

Weisz J (1982) In vitro assays of aromatase and their role in studies of estrogen formation in target tissues. Cancer Res 42: 3295s-3298s.

Westley BR, Salaman DF (1976) Role of oestrogen receptor in androgen-induced sexual differentiation of the brain. Nature 262:407-408.

Wozniak A, Hutchison RE, Morris CM, Hutchison JB (1998) Neuroblastoma and Alzheimer's disease brain cells contain aromatase activity. Steroids 63:263-267.

Wright CL, Schwarz JS, Dean SL, McCarthy MM (2010) Cellular mechanisms of estradiol-mediated sexual differentiation of the brain. Trends Endocrinol Metab 21:553-561.

Wu MV, Manoli DS, Fraser EJ, Coats JK, Tollkuhn J, Honda S, Harada N, Shah NM (2009) Estrogen masculinizes neural pathways and sex-specific behaviors. Cell 139:61-72.

Yague JG, Azcoitia I, DeFelipe J, Garcia-Segura LM, Munoz A (2010) Aromatase expression in the normal and epileptic human hippocampus. Brain Res 1315:41-52.

Yague JG, Garcia-Segura LM, Azcoitia I (2009) Selective transcriptional regulation of aromatase gene by vitamin $\mathrm{D}$, dexamethasone, and mifepristone in human glioma cells. Endocrine 35:252-261. 
Yague JG, Lavaque E, Carretero J, Azcoitia I, Garcia-Segura LM (2004) Aromatase, the enzyme responsible for estrogen biosynthesis, is expressed by human and rat glioblastomas. Neurosci Lett 368:279-284.

Yague JG, Munoz A, de Monasterio-Schrader P, Defelipe J, GarciaSegura LM, Azcoitia I (2006) Aromatase expression in the human temporal cortex. Neuroscience 138:389-401.
Yague JG, Wang AC, Janssen WG, Hof PR, Garcia-Segura LM, Azcoitia I, Morrison JH (2008) Aromatase distribution in the monkey temporal neocortex and hippocampus. Brain Res 1209:115-127.

Zhou L, Fester L, von Blittersdorff B, Hassu B, Nogens H, Prange-Kiel J, Jarry H, Wegscheider K, Rune GM (2010) Aromatase inhibitors induce spine synapse loss in the hippocampus of ovariectomized mice. Endocrinology 151:1153-1160.

(Accepted 5 February 2011)

(Available online 12 February 2011) 